\title{
Supporting Factors of Buying Transactions Based on Local Wisdom in Aceh
}

\author{
Sulaiman Sulaiman \\ Lecturer of Law Faculty, Malikussaleh University, Aceh, Indonesia \\ Jalan Jawa, Kampus Bukit Indah, Muara Satu, Lhokseumawe, Aceh, Indonesia, sulaiman@unimal.ac.id \\ Yulia Yulia (Corresponding author) \\ Lecturer of Law Faculty, Malikussaleh University, Aceh, Indonesia \\ Jalan Jawa, Kampus Bukit Indah, Muara Satu, Lhokseumawe, Aceh, Indonesia, yulia@unimal.ac.id
}

The research is financed by Malikussaleh University, Aceh, Indonesia

\begin{abstract}
The people of Aceh still use the concepts of Islamic law and customary law in the practice of buying and selling land and house objects such as: consent and kabul, langgeh rights, bright selling, cash and friendship. The concept of elements of Islamic law and customary law has been emphasized in Law Number 11 of 2016 concerning the Government of Aceh. This study aims to analyze the supporting factors for strengthening the concept of strengthening elements of Islamic law and customary law based on local wisdom in Aceh. This study uses empirical juridical research. The results of the study found that Islamic Law and Customary Law are factors supporting buying and selling transactions as local wisdom in Aceh. The Ijab and Kabul processes in buying and selling transactions are carried out by the people of Aceh with the belief for the validity of the actions.
\end{abstract}

Keywords: buy and sell, Islamic law, customary law, aceh, local wisdom

DOI: $10.7176 / \mathrm{JLPG} / 118-16$

Publication date: February $28^{\text {th }} 2022$

\section{Introduction}

The social system is formed from the interrelation and interaction carried out by individuals. Society is a social system that has a certain level of freedom in meeting its needs. The absolute level of freedom is impossible to achieve, because it is contrary to its essence as a sub-system related to its environment. This freedom is indicated by the stability of the exchange relationship with the environment and the ability to control the exchange, to meet the needs of the community itself. ${ }^{1}$

Buying and selling transactions for land and house objects, including buying and selling transactions for other objects that are also carried out by the community, are a necessity of life in an ever-evolving society. ${ }^{2}$ Society is a system built on a set of common values that are interrelated by its members in a socialization process. Through this socialization process, an individual learns about how he must act in accordance with the norms that apply in his social environment, how he must act and react to the rules and values that apply in his environmental formation process. ${ }^{3}$ This article will analyze the factors that support buying and selling transactions based on local wisdom in Aceh.

\section{Research Methodology}

This study looks at the importance of the concept of strengthening the legal elements of buying and selling in Aceh. An analytical study was conducted on the strengthening of elements of Islamic law and elements of customary law of the people of Pidie Jaya Regency, in buying and selling land and house objects, which still use the concepts of Islamic law and customary law. Then the two concepts of the legal system are still used by the community in buying and selling land and house objects. This study uses an empirical juridical methodology, with qualitative analysis in this study aimed at sharpening, enriching and developing the qualitative data itself.

\section{Result And Discussion}

\subsection{Islamic law as a supporting factor for buying and selling transactions}

The sale and purchase transactions for land and house objects, including buying and selling transactions for other objects that are also carried out by the community, are a necessity of life in an ever-evolving society. According to the majority of scholars, the pillars of buying and selling are: muaqidain (seller and buyer), sigat

\footnotetext{
${ }^{1}$ Ronny Hanitiyo Soemitro, Studi Hukum dan Masyarakat, (Bandung: Alumni, 1982), p. 69.

${ }^{2}$ Arijulmanan. (2018). Revitalisasi Syariat Islam Sebagai Pedoman Hidup Manusia. Al-Mashlahah: Jurnal Hukum Islam dan Pranata Sosial Islam, 06(02).

${ }^{3}$ Adam Podgorecki dan Cristopher J. Whelen (ed), Pendekatan Sosiologi Terhadap Hukum, (Jakarta: PT. Bina Aksara, 1987$)$, p. 112.

* Corresponden Author
} 
(pronunciation of consent and accept), there are goods being traded, and price. ${ }^{1}$ First, Conditions for the person having the contract, the fiqh scholars agree that the person entering into the sale and purchase contract must meet the requirements; a. Reasonable and old enough. Thus, buying and selling carried out by small children and crazy people who have not reached puberty is not legal.

According to Imam Hanafi, if the contract he does brings benefits to him, such as receiving grants, wills, and alms, then the contract is valid. If the contract brings harm to him, such as lending property to others, donate it is not justified according to law. According to the majority of scholars, the person who carries out the sale and purchase contract must be mature, mature and reasonable. If the person who has the contract is still mumayyiz (underage) then the sale and purchase contract is invalid), ${ }^{2}$ even if he gets permission from his guardian. $b$. The person performing the contract is a different person, meaning that a person cannot act as a buyer and a seller at the same time. c. Mukhtar, meaning not under pressure and coercion by other parties. ${ }^{3}$

Second, Conditions related to accept consent, Fiqh scholars agree that the main business in buying and selling is the willingness of both parties. This willingness can be seen at the time of the contract. Hand over and acceptance must be clearly disclosed in transactions that are binding on both parties, such as buying and selling contracts and leasing. If hand over and accept have been pronounced in the sale and purchase contract, the ownership of the goods and money has changed hands. Hand over and accept in the sale and purchase contract are one of the elements of Islamic law that must be carried out in buying and selling transactions. ${ }^{4}$

The buying and selling transactions that want to be studied in this study are only limited to land and houses objects. The restriction of the object to see in the sale and purchase transaction is carried out by the people of Pidie Jaya Regency, who still use elements of Islamic law such as sayings of hand over and accept, and other elements such as if you want to sell the land and house objects, especially must be notified first to the neighbors, which consist of the front, back, right and left neighbors. Because the two objects are in the category of high nominal value, which should have consent and acceptance in the implementation of buying and selling transactions, causing a legal relationship between the seller and the buyer to be bound, which is called a contract. ${ }^{5}$ If a sale and purchase transaction is carried out on land and house objects, what must be considered is the validity of a contract, the existence of pillars and conditions as elements in an Islamic legal agreement. One of the elements in the sale and purchase contract according to Islamic law is the consent and acceptance.

The main pillars in the sale and purchase agreement according to Imam Hanafi are consent and acceptance, namely expressions or statements of surrender of property rights on the one hand and expressions or statements of acceptance on the other. The existence of consent and acceptance in this transaction is an indication of consensual consent from the parties who entered into the transaction. Hand over and accept are a form of convincing indication of the existence of consensual feelings. If at the present time other methods are found that can be placed as indications, such as nodding to each other or signing a document, then this has fulfilled the elements of a transaction. For example, a sale and purchase transaction in a supermarket, the buyer has handed over the money and the seller through his clerk at the counter has provided a receipt slip, then the sale and purchase is valid. ${ }^{6}$

The scholars agreed to exclude the obligation of hand over and accept to objects of small value buying and selling that usually take place in fulfilling daily life, such as buying and selling a pack of cigarettes. For this purpose it is considered, if the seller has shown the goods and the buyer has shown the money. This method is called mu'atah. For example, buying a can of fresh drink in an automatic machine where the buyer has entered the coins that have been provided and the seller through the machine has handed over a can of fresh drink as ordered.?

If the seller says hand over, then the buyer leaves before saying accept or the buyer carries out other activities that have nothing to do with the sale and purchase, then he says accept, then according to the agreement of the Fiqh scholars the sale and purchase is not valid, even if they hold the opinion that the consent does not have to be answered immediately accepted. ${ }^{8}$ Scholars of the Shafi'i school and the Hambali school are of the opinion that the distance between consent and acceptance is not too long, because it can lead to suspicions that the object of the sale and purchase discussion has changed, whereas according to the Hanafi school and the Maliki school of thought, it is permissible to accept consent and acceptance mediated by time, assuming that the buyer has had a chance to think.

\footnotetext{
${ }^{1}$ Adam Podgorecki dan Cristopher J. Whelen (ed), Pendekatan Sosiologi Terhadap Hukum, (Jakarta: PT. Bina Aksara, 1987), p. 112.

${ }^{2}$ Syaifullah, S. (2014, December 17). Etika Jual Beli Dalam Islam. HUNAFA: Jurnal Studia Islamika, 11(2), $371-387$.

3 Amir Syarifuddin, Garis-Garis Besar Fiqih, p. 195.

${ }^{4}$ Juhrotul Khulwah, (2019), Jual Beli Dropship Dalam Prespektif Hukum Islam, Al-Mashlahah Jurnal Hukum Islam, Vol 7, No 1, p. 101-115. Ibnu 'Abidin, Radd al-Mukhtar 'ala ad-Durr al-Mukhtar, juz IV (Beirut: Dar al-Fikr, t.t), p.5.

${ }^{6}$ Retno Dyah Pekerti, Eliada Herwiyanti, Transaksi Jual Beli Online dalam Perspektif Syariah Madzhab Asy-Syafi’I, Jurnal Bisnis, Ekonomi dan Akuntansi, 20(2) 2018.

${ }^{7}$ Habibullah, E.S. (2017). Hukum Ekonomi Syariah dalam Tatanan Hukum Nasional. Al-Mashlahah: Jurnal hokum Islam dan Pranata Sosial Islam, 05(10).

${ }^{8}$ Susiawati, W. (2017). Jual Beli Dan Dalam Konteks Kekinian, Ekonomi Islam, 8(02), 171-184
} 


\subsection{Customary Law as a Supporting Factor in Buying and Selling Transactions}

The sale and purchase transactions of land and house objects that contain elements of Islamic law are carried out by the Acehnese people of Pidie Jaya Regency, in addition, in the buying and selling transactions, elements of customary law are known as the legal cultural wealth of the Acehnese people. The law that grows and develops in a certain area is the result of a process of community interaction. This law is intended to regulate people's lives in order to achieve peace and tranquility. Furthermore, the law that grows and develops in a certain area is based on social values, cultural aspects and structural factors of society. An example of customary law is a law that is formed based on the social values of a particular society.

Regarding property rights according to customary law, Imam Soetiknyo explained as follows: Land with customary rights is whatever the term is, without proof of ownership rights and not registered anywhere, but known and recognized as legal by the community where the land is located. ${ }^{1}$ Even though according to Article II paragraph (1) of the Conversion Provisions, these rights have been converted into the property rights are Article 20 paragraph (1), but this is still not widely implemented in the regions.

In customary law, "selling and buying land" is not a legal act which is what is called an "obligatory agreement". The sale and purchase of land in customary law is a legal act of transferring rights with cash payments. This means that the mutually agreed price is paid in full at the time of the sale and purchase in question. In customary law there is no definition of juridical surrender as the fulfillment of the seller's legal obligations, because what is called a "land sale and purchase" is the transfer of land rights that are sold to the buyer who at the same time pays the seller a price that has been mutually agreed upon. ${ }^{2}$ Based on the system and procedures for buying and selling according to customary law, it can be concluded that the legal requirements for a legal act of buying and selling land according to customary law are the existence of an object rather than a sale and purchase in the form of land and money (price), the existence of an agreement between the parties (the seller and the buyer), and there are witnesses who witnessed the legal actions of buying and selling.

The system of buying and selling land in customary law adheres to a cash, concrete, clear and real system, meaning that every relationship must be seen as real. This is because indigenous peoples are still very simple, so that in a land sale transaction it is only binding if the transaction is seen to be concrete and has actually taken place, namely evidenced by an exchange, in the form of surrendering land as an object at the same time handing over cash as payment.

In connection with the above, Imam Soetiknyo gave the meaning of "light" which explained that the transfer of land rights according to custom must be supported (medewerking) by the Head of the Tribe/Legal Community/Village so that the act is clear and legal (rechtsgeldigheid) borne by the Tribal Chief, the community village law. Apart from that, the Customary Head must also ensure that the rights of heirs, neighbors (buren recht) and the rights of others are protected tribes are not violated if the customary land rights are to be released or sold by contract. ${ }^{3}$

The provisions of the transactions above will not be carried out without the support of village apparatus, in this case community leaders and other instruments, if the legal action is carried out, it is not clear, illegal and does not apply to third parties. In Aceh Province, including Pidie Jaya Regency, the community group that meets the requirements as a customary law community is the mukim. Mukim is a customary law community unit in the province of Aceh which consists of several villages. In the legal alliance called the customary law community, each member feels there is a bond and behaves and acts as a unit, it is embedded in their lives. This opinion can be accepted by almost everyone, because it is human nature to always live in groups whether due to genealogical or territorial factors or both. To maintain group life there are rules even though they are very simple. There is a leader, in this case the village head as the head of the village or who manages it and of course that are material and immaterial wealth.

In the event of a sale and purchase of land and house objects in the City of Pidie Jaya Regency, the legal rules governing buying and selling in general still rely on the three legal systems such as Islamic law, customary law and civil law generally accepted in Indonesia. However, the use of the rules of Islamic law and customary law as elements in buying and selling transactions is still alive in the midst of society, this is evidenced when there is a sale and purchase transaction between the Acehnese and the Acehnese, the Acehnese and the immigrant community, the existence of a contract in the form of consent and acceptance. as elements in Islamic law, besides that, there are also elements of customary law.

\footnotetext{
${ }^{1}$ Ramon, T. (2018). Tinjauan Yuridis Terhadap Keabsahan Dan Kekuatan Alat Bukti Jual Beli Tanah Menurut Hukum Adat. JURNAL HUKUM DAS SOLLEN, 2(1).

${ }^{2}$ Abubakar, Lastuti. "Revitalisasi hukum adat sebagai sumber hukum dalam membangun sistem hukum Indonesia." Jurnal Dinamika Hukum 13.2 (2013): 319-331.

${ }^{3}$ Yunus, Ahyuni, and Ahmad Ali Muddin. "Penyelesaian Sengketa Tanah Ulayat Yang Telah Bersertifikat Berdasarkan Hukum Adat MalindAnim." Jurnal Kertha Patrika 41.3 (2019): 206-221.
} 


\section{Conclusion}

A land sale and purchase transaction based on customary elements, in which the land owner as the seller hands over his parcel of land to another person as a buyer forever by paying a sum of money in cash or in installments, which is known as selling off. In the past, most of the sale and sale of land was carried out in writing under the hand, with or without the testimony of village officials. Where is now in the buying and selling transactions must be with village equipment. The nature of this freelancing is clear and cash, meaning that it is clear that it is known to the neighbors and relatives and the payment is made. Things like this are known in the Acehnese community as claim rights, meaning rights attached to neighbors, if you want to sell land objects and house objects, you must first notify the neighbors. In addition, there are other rights that are still alive in the community, such as rights in buying and selling transactions in the form of land objects and house objects. The Land and house objects in the future which are the responsibility of the village apparatus to complete them.

\section{References}

Arijulmanan. (2018). Revitalisasi Syariat Islam Sebagai Pedoman Hidup Manusia. Al-Mashlahah: Jurnal Hukum Islam dan Pranata Sosial Islam, 06(02).

Abdul Rahman Gazali, et al, Fiqh Muamalat (Jakarta: Prenada Media Group, 2010).

Abubakar, Lastuti. "Revitalisasi hukum adat sebagai sumber hukum dalam membangun sistem hukum Indonesia." Jurnal Dinamika Hukum 13.2 (2013): 319-331.

Chairuman Pasaribu, et al, Hukum Perjanjian dalam Islam (Jakarta: Sinar Grafika Offset, 2004).

Dahlan, Hak Masyarakat Hukum Adat Atas Tanah di Provinsi Daerah Istimewa Aceh,(Banda Aceh: Kanun Jurnal Ilmu Hukum, NO.28 Tahun X April, 2001).

Habibullah, E.S. (2017). Hukum Ekonomi Syariah dalam Tatanan Hukum Nasional. Al-Mashlahah: Jurnal hokum Islam dan Pranata Sosial Islam, 05(10).

Juhrotul Khulwah, (2019), Jual Beli Dropship Dalam Prespektif Hukum Islam, Al-Mashlahah Jurnal Hukum Islam, Vol 7, No 1, p. 101-115.

Muhammad Abduh, Aturan Jual Beli, Jual Beli Tanpa Ucapan,Internet, di akses tanggal 13 Pebruari 2011.

Ramon, T. (2018). Tinjauan Yuridis Terhadap Keabsahan Dan Kekuatan Alat Bukti Jual Beli Tanah Menurut Hukum Adat. JURNAL HUKUM DAS SOLLEN, 2(1).

Retno Dyah Pekerti, Eliada Herwiyanti, Transaksi Jual Beli Online dalam Perspektif Syariah Madzhab AsySyafi'I, Jurnal Bisnis, Ekonomi dan Akuntansi, 20(2) 2018.

Susiawati, W. (2017). Jual Beli Dan Dalam Konteks Kekinian, Ekonomi Islam, 8(02), 171-184

Syaifullah, S. (2014), Etika Jual Beli Dalam Islam. Hunafa: Jurnal Studia Islamika, 11(2), 371-387.

Yunus, Ahyuni, and Ahmad Ali Muddin. "Penyelesaian Sengketa Tanah Ulayat Yang Telah Bersertifikat Berdasarkan Hukum Adat Malind-Anim." Jurnal Kertha Patrika 41.3 (2019): 206-221. 